\title{
Assessment of Property Management Service Quality of Purpose Built Office Buildings
}

\author{
Zarita Ahmad Baharum \\ Graduate Centre Department \\ Faculty of Architecture Planning and Surveying \\ University Technology MARA (UiTM), 40450 Shah Alam, Malaysia \\ Tel: 60-3-5544-4216 E-mail: zarit928@salam.uitm.edu.my \\ Abdul Hadi Nawawi \\ Graduate Centre Department \\ Faculty of Architecture Planning and Surveying, \\ University Technology MARA (UiTM), 40450 Shah Alam, Malaysia \\ Tel: 60-3-5521-1568Ｅ-mail: abdulhadinawawi@yahoo.com \\ Zainal Mat Saat \\ Graduate Centre Department \\ Faculty of Architecture Planning and Surveying, \\ University Technology MARA (UiTM), 40450 Shah Alam, Malaysia \\ Tel: 60-19-311-1301Ｅ-mail: zaimasa@salam.uitm.edu.my
}

\begin{abstract}
Service quality has many benefits including achieving and sustaining a competitive advantage as determinant of business success and failure and as a barometer of corporate performance. In the service industry like the property management, quality and perception of quality is essential. Thus, the need to deliver quality service is imperative in order to retain tenants as services is the criteria upon which clients, customers and users of real estate product and services differentiate one organization from another. The purpose of the study discussed in this paper is to develop PROPERTYQUAL, a service quality instrument for property management profession and to contribute to research that analyses the relationship between expectations and perceptions of service quality. It also aims to use a gap analysis based model to measure tenants' perceptions of service quality in the property management of purpose built office buildings in Malaysia. This study utilizes a combination of quantitative and qualitative approach to research which allow triangulation of the findings and also enable the use of one method to inform the other, reveal paradox or contradictions, and extend the breadth of inquiry. The Cronbach alpha and CFA analysis confirmed that PROPERTYQUAL is a robust instrument to measure service quality in the property management services. The current findings do provide some important insights of understanding the variables that contribute to service quality and tenants satisfaction of property management services. This research has added to the base of knowledge regarding the assessment of service quality and tenant satisfaction in property management services and highlights areas for future research.
\end{abstract}

Keywords: Service quality, Property management, Purpose built office buildings

\section{Introduction}

Property management is a very demanding and challenging profession. It involves organizing an efficient system as well as directing, coordinating and controlling all the skills available towards maximizing income from a property and at the same time ensuring maximum protection of its fabric from deterioration and wastage through proper upkeep and maintenance (Scarrett, 1986). 
The requirement for high standard of service quality in property management has grown through the years due to the fact that tenants have become more demanding in an increasingly competitive business environment.

Since the beginning of 1990s, both marketing and management literature and research have witnessed a growing interest in service quality (Parasuraman et al, 1985; 1988; Gronroos, 1998). Delivering service quality is considered an essential strategy for success and survival in today's competitive environment (Parasuraman et al 1985; Schieder and White, 2004). Property industry is one of the service industries that play a significant role in most economies. Thus, this study aims to develop a service quality instrument for property management services and hence, used the instrument to measure the service quality in property management services in Malaysia

\section{Problem Statement}

Tenants are now increasingly aware of and concerned about the level of service they receive. Bell (2001) claimed that the top criteria for improving retention are service improvements and service relationship. This means that property managers must be able to create lasting tenant relationships, achieve the highest level of tenant satisfaction and retention, and able to combine industry knowledge with their business acumen (CEL \& Associates, 2001). Moreover, office building has become even more sophisticated and applying high technology - and this requires a very knowledgeable manager to manage it effectively and efficiently. These have also made the property management profession a rapidly growing profession, attracting many new entrants into the market (Chin \& Poh, 1999). Therefore in order to remain competitive, property manager must listen and respond to tenants' needs, concerns and expectations, as well as opinions, and use this information to quantify their performance and compare them with best practice (Muhlebach, 1998).

Chin \& Poh (1999) argued that due to the increase in expectations of tenants and the growth in the economy, there is a growing awareness of the need among buildings owners, professionals, and the authorities to raise the standard of property management practice. Their studies in Singapore showed the profession is lagging behind their counterparts such as manufacturing and constructions in implementing quality as part of their management tools. A review on The Surveyor, a professional journal by Institution of Surveyor Malaysia, since 1980 to date reveals that no article has mentioned about service quality in the property management profession in Malaysia. A study on the status of property management practice in Malaysia showed that only $30 \%$ of the property managers use quality as their management tool (Zarita et al, 2004). It also showed that property managers have focused only on those performance variables that can be easy and readily available for example the investment based performance measurement and the occupancy cost performance. That is basically the reason why property management industry is very slow in adopting such measure. The property managers have been forced to measure end results as opposed to the incremental processes that actually combine to make up the end result. These measurements tend to explain 'what' but provide little insight into the 'why'. As a result, the manager can only hypothesize or make guess regarding the actual cause (Schwenker, 1999).

In the property industry, outstanding tenants' service means meeting and anticipating the tenant needs. This is because tenants are the lifeblood of a property management companies. Negative tenant relations can have a serious effect on property returns, as letting space is the prime income generator for the owner and the management company. A recurring problem is that tenants' needs and dissatisfactions are discovered too late, as when a tenant announces he will not be renewing the lease. There is no evidence that an instrument of service quality in the property management service has ever been established. Measurement is a prerequisite for anything which is to be improved and property management is no exception. Thus, this research is aimed at developing a service quality instrument for the property management services.

A study on the status of property management practice in Malaysia showed that only $30 \%$ of the property managers use quality as their management tool. It also showed that property managers have focused only on those performance variables that can be easy and readily available for example, the investment based performance measurement and the occupancy cost performance (Zarita et al, 2004). That is basically the reason why the property management industry is very slow in adopting such a measure. The property managers have been forced to measure end results as opposed to the incremental processes that actually combine to make up the end result. These measurements tend to explain what but provide little insight into the why. As a result, the manager can only hypothesise or make guess regarding the actual cause of their services or performance (Schwenker, 1999).

Managers need more useful performance data to help answer the 'why'. Thus, to answer the why, the property manager needs to focus on tenant-based performance measurement in order to set themselves apart from their competitor. It is imperative for the owner to attract and retain satisfied tenants for their property investments. In order to retain tenants, the property manager needs to pay more attention to the tenants, and that starts with a solid analysis of the company's performance (Muhlebach, 1998). Without this clear vision and correctly defined business practices and processes, an organization is doomed to lackluster performance and loss of business. 
Despite the importance of measuring service quality across industries and nationwide, little empirical research has been conducted in the delivery of professional practice of property management services in Malaysia. This research is therefore, an effort to gain insight into the service quality of tenants and the property managers.

\section{Service Quality}

Service quality is an abstract and elusive concept because of the well-known distinctive features of services intangibility, perishability, heterogeneity, and inseparatability of production and consumption (Zeithaml et al, 1985; Rust et al, 1996; Kotler and Armstrong, 2001). It is due to these features that definition of quality can vary from person to person, and from situation to situation (Kandampully, 2002).

Delivering quality service has many benefits including achieving and sustaining a competitive advantage (CEL and Associates Inc, 1996; Lee and Dean, 1998), as determinant of business success and failure (BOMA, 1998) and as a barometer of corporate performance (Javitch et al, 1995). In the service industry like the property management, quality and perception of quality is essential. Thus, the need to deliver quality service is imperative in order to retain tenants as services is the criteria upon which clients, customers and users of real estate product and services differentiate one organisation from another (CEL and Associates Inc, 1996).

Perceived service quality, was defined as the difference between customer expectations and perceptions or also known as gap analysis (Parasuraman et al, 1985; 1988). The gap analysis model is based on the expectancy disconfirmation theory. Expectancy disconfirmation theory predicts that customers will judge that quality is low if performance does not meet their expectations and quality increases as performance exceeds expectations (Oliver, 1980). Hence, customers' expectations serve as the foundation on which service quality will be evaluated by customers. In addition, as service quality increases, satisfaction with the service and intentions to reuse the service increase.

\section{A Service Quality Model}

A model is useful in providing insights into the complexity of service quality. SERVQUAL is an instrument to specifically measure service quality (Parasuraman et al 1985, 1988; Zeithaml and Bitner, 2003). SERVQUAL is composed of the five factors, reliability, assurance, tangible, responsiveness, and empathy. Parasuraman et al (1988) claimed that SERVQUAL provides a basic framework through its expectations or perceptions format encompassing statements for each of the five service quality dimensions. The skeleton, when necessary, can be adapted or supplemented to fit the characteristics or specific research needs of a particular organisation. Babakus and Boller (1992) commented that the domain of service quality may be factorially complex in some industries and very simple and uni-dimensional in others. The number of service quality dimensions is dependent on the particular service being offered. Nonetheless, researchers generally agree that the scale items are good predictors of overall service quality (Swartz and Brown, 1989; Carman, 1990; Parasuraman, 1998; Bolton and Drew, 1991; Cronin and Steven, 1992). In fact, Gronroos (1998) has labeled SERVQUAL as the best measurement for service quality. Since the introduction of the SERVQUAL, it has become the favourite, the most adopted, the best service quality measurement applied across industries and nationwide. The majority of studies do support the applicability of the SERVQUAL instrument as the only tool that has been tested statistically in terms of validity and reliability, for measuring service quality.

There is a dearth of research into service quality in the property industry. To date there are six service quality research and all in the estate agency services (Johnson et al, 1988, Mc Daniel et al, 1994, Nelson et al, 1995, Seiler et al, 2000, Teoh, 2004 and Pratibha et al, 2005). This support the much needed research of service quality in the property management services as none has been done to date, particularly in property management service in Malaysia.

\section{The Conceptual Framework}

In order to develop a service quality instrument or PROPERTYQUAL, a conceptual framework needs to be established. The process of developing a conceptual framework involves two stages. Firstly is the identification of constructs to be included in the framework and secondly is the identification of dimensions. This chapter has looked at the service quality model from various studies, namely Gronroos (1998), Parasuraman et al (1985, 1988), Rust and Oliver (1994) and Brady and Cronin (2001). The comparison from various studies can be concluded that there are at least two constructs namely construct before and after the quality action is needed in a service quality framework. Any additional construct can be added accordingly or depending on the industry understudy. This study has identified Functional as the construct before quality action and Technical as the construct after quality action.

The identification of the dimensions involves dimensions for the Functional construct and dimensions for Technical construct. The researcher has adopted Parasuraman et al (1988) the five service quality dimensions to reflect the Functional construct namely, reliability, assurance, tangibles, empathy and responsiveness. The justification for this is because (i) the five dimensions is short and comprehensive to measure the Functional construct, (ii) this is based on empirical and statistical analysis, and (iii) it has the SERVQUAL instrument. Technical dimensions are solely based on literature review. Five dimensions have been chosen namely cleanliness, building services, signage, security and parking as a robust and comprehensive to cover the property management services. Additional dimension to be included 
in this framework is Image construct to reflect the important of branding and competitive advantage of image in property industry. The focus of image in this study is on what is inside the four walls and excluding the design of a building. This is due to the fact that design is very subjective and the tenants occupy the building after it has been built. In addition, the researcher has verified the five dimensions of Technical construct and one dimension of Image construct using the panel of property managers in practice. The feedback is used to confirm the dimensions in this study.

It is essential to look at the development of service quality model and dimensions from previous studies. A synthesis of the service quality model will give rise to important elements or constructs that should be included in a model. In addition a synthesis of dimensions from previous studies will give rise to dimensions that is appropriate to a particular study i.e. property management services. The analysis is meant to look at the holistic view of the previous studies and comprehend the elements and dimensions used in the studies. Services are unique in nature and no two services are the same, thus each of the studies has been tailored to a particular services or industry understudy.

The development of a conceptual framework for service quality in the property management services is important in order to measure the gap between tenants' and property managers' expectations and perceptions. This is due to the fact that there is of no evidence that a service quality framework for property management services is in existence. This conceptual model has identified the dimensions and construct for property management services. The service quality framework for property management services is illustrated in Figure 1 below.

There are three stages in the framework development. The first stage is the dimensions of service quality for the property management services. For the purpose of this study the dimensions is divided into two groups, the SERVQUAL and the property dimensions. SERVQUAL is used in this framework to demonstrate that this study is a modified SERVQUAL which has been developed by Parasuraman et al $(1985,1988)$. The purpose of this modification is to reflect the industry or service understudy or particularly the property management service. The second phase explains the constructs of property management service. There are three constructs that explained property management service quality; (i) functional which represent element/service judged before (five dimensions), (ii) technical represent element/services judged during (five dimensions), and (iii) image represent the additional elements which is the building aesthetics (one dimension). The third stage involves a gap analysis (Zeithaml et al, 1985) i.e. measuring the gap between level of expected service and perceived service of both the tenants and property managers. A gap analysis provides a systematic framework to identify the relevant outcomes and benchmark measures necessary to determine service quality beyond satisfaction measures (Selz, 1997).

Based on this conceptual framework, a service quality instrument or PROPERTYQUAL is established. The PROPERTYQUAL is a service quality questionnaire developed in the real estate context focusing on the purpose built office buildings. The target groups for this study are the tenants as well as the property managers of purpose built office buildings.

\section{PROPERTYQUAL as a Service Quality Instrument}

The instrument used in this study was a modification of SERVQUAL (Parasuraman et al 1985, 1988), which has a 54 item self completed questionnaire that measured customer expectations and perceptions of service quality. The instrument that has been developed is named Property Management Service Quality Instrument or PROPERTYQUAL. PROPERTYQUAL measures expectations and perceptions of service quality along five dimensions of service quality determinants (Parasuraman et al 1998) and other six dimensions.

SERVQUAL was modified in the present study to reflect the nature of property management services. Parasuraman et al (1988) indicated that such modifications were appropriate and do not represent difficulties related to the reliability and validity of the instrument. The revisions included (i) using the property management and tenant in the instrument rather than company and customer, (ii) adding new dimensions to the instrument to reflect the property management profession. The new dimensions or the property dimension includes cleanliness, building service, signage, security, parking, and building aesthetics. Table 1 below summarizes the characteristics of SERVQUAL and PROPERTYQUAL.

\section{Research Methodology}

\subsection{Research objectives}

This study has addressed the following objectives and research questions;

(i) To develop PROPERTYQUAL, a service quality instrument for property management services.

(ii) To measure tenants' and property managers' perceptions of service quality in the property management of purpose built office buildings in Malaysia using PROPERTYQUAL.

\subsection{Research design}

A mixed-methodology or triangulation design of the study incorporates the use of quantitative and qualitative paradigm (Creswell, 1994). Results of the quantitative mail survey in the study are used to answer research question 1 to 5 . In 
addition results from the qualitative are used to verify the findings and to further explain factors that influence service quality amongst tenants' and property managers.

The study was conducted to privately owned purpose built office buildings in Kuala Lumpur with a population of 318 buildings. For the purpose of this study, the whole population of purpose built office buildings in important location was considered. The reason for this is due to the low rate of response, thus, it is appropriate that we take the whole population rather than the subset of it.

The instrument used is PROPERTYQUAL, a modified SERVQUAL developed by Parasuraman et al $(1985,1988)$. The SERVQUAL measure has proven to be reliable in other applications. The variables for this study are the 11 dimensions of service quality as presented by 54 scale items which has been developed purposely to reflect the service understudy. Data was collected by method consistent with the research design. Data analysis was also based on the research design, and also assumptions of normality for the population. Figure 2 provides a summary of the research design.

\section{Empirical Findings}

\subsection{Internal Consistency of the PROPERTYQUAL Instrument}

The internal consistency of the PROPERTYQUAL instrument was assessed through eleven dimensions of Functional, Technical and Image constructs. The five dimensions; tangibles, responsiveness, empathy, reliability and assurance were used as indicators of the Functional construct. Other dimensions; cleanliness, building services, signage, security and parking were used as indicators of Technical construct while building aesthetics was used as an indicator of Image construct. Both expectations and perceptions scores for each dimension were assessed using Cronbach's Alpha. The results are summarised in Table 2.

It can be clearly seen in Table 2 that all the dimensions of PROPERTYQUAL have a high internal consistency as the Alpha's coefficient for both expectations and perceptions are above 0.90. Furthermore, the overall Alpha for the entire 54 items of expectations and perceptions are also high ( 0.992 and 0.989 , respectively). Therefore, it can be concluded that PROPERTYQUAL instrument is reliable and applicable to be used for measuring property management services quality.

\subsection{Goodness-of-Fit of the Model}

Confirmatory factor analysis (CFA) was carried out to assess the overall goodness-of-fit of the model being hypothesised. The model fit for each construct was assessed using Normed Fit Index (NFI), Relative Fit Index (RFI), Incremental Fit Index (IFI), Tucker-Lewix Index (TLI), Comparative Fit Index (CFI) and Root-Mean-Square Residual (RMR). For the index, values of 0.90 or higher suggest that the data fit the model well (Bentler and Bonett, 1980).The smaller the RMR the better the goodness of fit. An RMR of 0 indicates a perfect fit. The results of confirmatory factor analysis (CFA) constructs in this study are summarised in Table 3.

Overall, the data fit the model well for all constructs as the index are above 0.90 though the data fit relatively well for technical $(\mathrm{NFI}=0.853, \mathrm{RFI}=0.836, \mathrm{IFI}=0.877, \mathrm{TLI}=0.863$ and $\mathrm{CFI}=0.877)$. Moreover, a small value of RMR for each construct supports that the data fit the model well. Therefore, no necessary changes were made for the structure of those constructs.

\subsection{The discrepancies of expectations and perceptions between tenants and property managers}

There are discrepancies of expectations and perceptions between tenants and property managers. Figure 3 below illustrates the discrepancies or gap scores between tenants and property managers. It showed that property managers were found to have lower gap scores in all dimensions than tenants. This concludes that property managers were less satisfied towards the perceptions of service quality compared to tenants.

This is due to the multidimensional characteristic of human being which in turn will be influence by culture, subculture, social class, family, friends, institutions, experiences, mass media, advertising etc. However, in regards to the property managers although they are the service providers but the discrepancies existed are basically influenced by the humanism characteristics of their sub-ordinate under the managers' supervision, which some of the sub-ordinate's actions (how they handle their job, courtesy, empathy etc.) is beyond the control of the managers.

\subsection{Property managers' perceptions}

Based on the mean score of perception (Table 4), property managers' perceptions perceived higher towards the dimensions of PROPERTYQUAL than tenants. This showed that property managers have better understanding of service quality than the tenants. This is basically due to the property managers understanding and awareness to manage property effectively and efficiently.

\subsection{Level of importance towards the dimensions of PROPERTYQUAL}

The study showed that based on the score of importance (Table 5) of the service dimension, reliability and responsiveness are found to be more important to the tenants than to the managers. However, assurance and reliability 
are shown to be more important to the managers than to the tenants. For the property dimensions, it was found that the tenants perceived cleanliness, security and building services as the top three ranking. Property managers on the other hand perceived cleanliness, and building services as the top three ranking.

\subsection{Signage and building aesthetics dimensions and tenants' overall service quality perception}

The study revealed that signage and building aesthetics have a positive effect on tenants' overall service quality perception. Signage has a greater influence compared to building aesthetics as indicated by the coefficients.

8.7 Reliability dimension and property managers' overall service quality perception

The multiple linear regression analysis found that only reliability has a significant positive effect on property managers' overall service quality.

\subsection{Technical and Image constructs and perceptions of overall service quality}

A path analysis has been carried out and revealed that Technical and Image influence perceptions of overall service quality in the property management of purpose built office buildings in Malaysia. Technical and Image constructs is actually property management based variables. This shows that service quality is highly influenced by property management related variable (cleanliness, building services, security, parking, signage and building aesthetics) and not by process or service delivery variables namely reliability, assurance, tangibles, empathy and responsiveness (Figure 4).

\section{Conclusion}

This study has developed PROPERTYQUAL, an instrument to measure service quality in property management of purpose built office buildings in Malaysia. PROPERTYQUAL has been developed thoroughly based on the conceptual framework and supported by the statistical analysis; it has been proved to be a reliable and valid instrument. Thus, this confirmed that PROPERTYQUAL is a robust instrument to measure service quality in the property management services. Further to that, this study has used PROPERTYQUAL to measure the perceived service quality of tenants and property managers. It is important to understand the expectations and perceptions of tenants and property managers in the property management services. The use of modified SERVQUAL and the development of PROPERTYQUAL offer the property management companies a diagnostic and disciplined methodological approach to assessing service quality within the property industry. The property management company is now able to make decisions about service improvement and tenants' satisfaction. Using PROPERTYQUAL allows the property manager to look specifically at the different dimensional measures of service quality in different ways. Figure 5 below illustrates the PROPERTYQUAL methodology.

This study is a starting point for the property management company to comprehend the relative degree of satisfaction and dissatisfaction of the tenants. This is a major contribution of this study whereby this information is non-existence before. Improvement and strategies for the betterment of the property management profession could be made accordingly. The study revealed that signage and building aesthetics would improve service quality and tenants' satisfaction. On the other hand, from a property management company's point of view, a lot of effort is needed to improve the property management companies on managing property effectively and efficiently and educating the property managers and staffs on how to deliver quality service. Although property management companies in Malaysia do measures their performance but none of the evaluation have provided information to management that PROPERTYQUAL provides for decision making.

The amount of research pertaining to service quality and tenants' satisfaction in the property industry is increasing, and there are still areas for future research. First, PROPERTYQUAL should also be tested to other property sectors; residential, commercial, industrial and special properties. This can also include comparing service quality and tenants' satisfaction between public and private buildings. Secondly, further research can analyze the barriers to implementing programs of service quality as well as tenants' satisfaction and ways to overcome those barriers. In addition, efforts should be made to narrow down the gap of perceptions between tenants and property managers. Thirdly, future research should also go beyond the dimensions investigated in this research to include other dimensions of quality, particularly culture which may be challenging in a multi-races country. Fourthly, in the context of property management services, future research can also explore new techniques (quantitative and qualitative) that provide meaningful insights into service quality and tenants' satisfaction.

\section{References}

Babakus and Boller, (1992). An empirical assessment of the SERVQUAL scale Journal of Business research, Volume 24, pp. 253-68.

Bell J (2001). A heavier load. National Real Estate Investor, (March).

Bentler, P.M. and Bonnet, D. G. (1980). Significance Tests and Goodness of-Fit in the Analysis of Covariance Structures. Psychological Bulletin 88,pp. 588-606. 
Bolton R. and Drew J. (1991). A Multistage Model of Customers' Assessments of Service Quality and Value, Journal of Consumer Research, Volume 17(4): pp. 375-384.

Brady \& Cronin. (2001). Some new thoughts on conceptualizing perceived service quality: a hierarchical approach, Journal of Marketing, Vol. 65, pp. 34-49.

Building Owner Management Association. (1998). State of the Industry Address from http://www.boma.org.

Carman J. (1990). Consumer Perceptions of Service Quality: An Assessment of the SERVQUAL Dimensions. Journal of Retailing, Volume 66(1): pp. 33-56.

CEL and Associates Inc. (2001). 'The Search for Quality Service', Strategic Advantage, /K7696, pp. 13-14.

Chin and Poh. (1999). Implementing quality in property management- the case of Singapore Journal of Property Management, Volume 17 Issue 4, pp. 310-320.

Creswell J W. (1994). Research Design: Qualitative \& Quantitative Approaches. Sage Publications

Cronin T J \& Steven A. (1992). Measuring Service Quality: A Reexamination and Extention. Journal of Marketing, 56/3 (1992), pp. 55-68.

Gronroos C. (1998). Marketing services: the case of a missing product. Journal of Business \& Industrial Marketing, 13/4/5, pp. 322-38.

Javitch, M., Allan H., Church, W. \& Warner, B. (1995). Enhancing professional service quality: feedback is the way to go. Managing service quality, Volume 5(03): pp. 29-33.

Johnson, Linda L., Dotson, Michael J. \& Dunlap, B.J. (1988). Service Quality Determinants and Effectiveness in The Real Estate Brokerage. Journal of Real Estate Research, Summer88, Vol. 3 Issue 2, pp. 21-38.

Kamdampully J. (2002). Services Management, the new paradigm in hospitality Pearson Education Australia Pty Limited.

Kotler P \& Armstrong G. (9 $9^{\text {th }}$. Edition). (2001). Principles of Marketing. Prentice Hall.

Lee C. \& Dean D. (1998). Winning applause. Journal of Property Management, Volume 63(2): pp. $42-45$.

Mc Daniel, J., Lourgand, Marc A. (1994). Real estate brokerage service quality: An examination. The Journal of Real Estate Research 9(3): pp. 339-351.

Muhlebach R F. (1998). Tenant surveys benchmark success for management firms. National Real Estate Investor, 40/2 (Feb), pp. 159-60.

Nelson, Susan Logan, Nelson, Theron R. (1995). RESERV: An Instrument for Measuring Real Estate Brokerage Service Quality. Journal of Real Estate Research, 1995, Vol. 10 Issue 1, pp. 99-114.

Oliver R. (1980). A Cognitive Model of the Antecedents and Consequences of Satisfaction Decisions, Journal of Marketing Research, Volume 17(4): pp. 460-469.

Parasuraman A, Zeithaml V A, Berry L.L (1985). A Conceptual Model of Service Quality and Its Implications for Future Research. Journal of Marketing, 49 (Fall), pp. 41-50.

Parasuraman A, Zeithaml V A \& Berry L.L. (1988). Servqual: A Multiple-Item Scale for Measuring Customer Perceptions', Journal of Retailing, 64/1, pp. 12-41.

Parasuraman A. (1998). Customer service in business-to-business markets: an agenda for research. Journal of Business \& Industrial Marketing, Volume 13(4/5): pp. 309-321

Pratibha A. D., Jeffrey W. O. (2005). Linking process and outcome to service quality and customer satisfaction evaluations: An investigation of real estate agent service International Journal of Service Industry Management; Volume: 16 Issue: 1; 2005 Research paper

Rust \& Oliver. (1994). Service quality: Insights and managerial implications from the frontier, in Rust and Oliver (eds) Service quality: New directions in theory and practice, Sage Publications, Thousand Oaks, Carlifonia

Rust, Zahorik \& Keiningham. (1996). Service Marketing, Harper Collins College Publishers, pg 332.

Scarrett, D. (1983). Property Management. London, New York E. \& F. N. Spon

Schneider B \& White S. (2004). Service Quality: Research Perspectives, SAGE Publications.

Schwenker, L. (1999). Measure twice, cut once. Journal of Property Management, Vol 64 Issue 2, pp. 78-83

Selz M. (1997). Toward a model of a gap analysis between leaders, investors and intermediaries in the mutual fund industry. Unpublished Doctor of Philosophy. Claremont, California. 
Seiler, Vicky L., Webb, James R. \& Whipple, Thomas W. (2000). Assessment of Real Estate Brokerage Service Quality with a Practicing Professional's Instrument. Journal of Real Estate Research, Jul-Oct2000, Vol. 20 Issue 1/2, pp. 105-118.

Swartz T \& Brown S. (1989). A Gap analysis of professional service quality. Journal of Marketing, Volume 53(2): pp. 92-98.

Teoh, P. H. (2004). Measuring Service Quality Using SERVQUAL: Findings and Insights from an Exploratory Study in the Malaysian real estate Agency Business. Unpublished PhD Thesis.

Zarita A.B, et al. (2004). A Status of Property Management Practice in Malaysia, Conference on Scientific \& Social Research 2005, Kuala Terengganu.

Zeithaml A., Parasuraman A. \& Berry L. (1985). A Conceptual Model of Service Quality and Its Implications for Future Research, Journal of Marketing, Volume 49: pp. 41-50.

Zeithaml V A \& Bitner M J (2003). Services Marketing: Integrating Customer Focus Across Firm, McGraw Hill.

Table 1. Summary of SERVQUAL and PROPERTYQUAL

\begin{tabular}{|c|c|c|}
\hline Name & SERVQUAL & PROPERTYQUAL \\
\hline Constructs & Functional & $\begin{array}{c}\text { Functional } \\
\text { Technical } \\
\text { Image }\end{array}$ \\
\hline Dimensions & $\begin{array}{c}\text { Reliability } \\
\text { Assurance } \\
\text { Tangibles } \\
\text { Empathy } \\
\text { Responsiveness }\end{array}$ & $\begin{array}{c}\text { Reliability } \\
\text { Assurance } \\
\text { Tangibles } \\
\text { Empathy } \\
\text { Responsiveness } \\
\text { Cleanliness } \\
\text { Building services } \\
\text { Signage } \\
\text { Security } \\
\text { Parking }\end{array}$ \\
\hline Item & 22 & 54 \\
\hline
\end{tabular}


Table 2. Reliability coefficients for eleven dimensions of PROPERTYQUAL

\begin{tabular}{|c|l|c|c|c|}
\hline \multirow{3}{*}{ Constructs } & \multicolumn{1}{|c|}{ Dimension } & \multirow{2}{*}{$\begin{array}{c}\text { Number of } \\
\text { items }\end{array}$} & \multicolumn{2}{c|}{ Alpha's Coefficient } \\
\cline { 4 - 5 } & & & Expectations & Perceptions \\
\hline \multirow{5}{*}{ Functional } & Reliability & 5 & .946 & .953 \\
\cline { 2 - 5 } & Responsiveness & 3 & .952 & .947 \\
\cline { 2 - 5 } & Assurance & 4 & .937 & .944 \\
\cline { 2 - 5 } & Empathy & 4 & .967 & .963 \\
\cline { 2 - 5 } & Tangibles & 5 & .967 & .968 \\
\hline \multirow{5}{*}{ Technical } & Cleanliness & 8 & .970 & .966 \\
\cline { 2 - 5 } & Building services & 12 & .978 & .971 \\
\cline { 2 - 5 } & Signage & 3 & .952 & .912 \\
\cline { 2 - 5 } & Security & 2 & .948 & .938 \\
\cline { 2 - 5 } & Parking & 3 & .953 & .954 \\
\hline Image & Building aesthetics & 5 & .949 & .964 \\
\hline
\end{tabular}

Table 3. Goodness-of-Fit Indicators of Models for the Three Constructs

\begin{tabular}{lccccc}
\hline Construct & ${ }^{\mathbf{a}}$ NFI & ${ }^{\mathbf{b}}$ RFI & ${ }^{\mathbf{c}} \mathbf{I F I}$ & ${ }^{\mathbf{d}} \mathbf{T L I}$ & ${ }^{\mathbf{e}} \mathbf{C F I}$ \\
\hline Functional & .933 & .921 & .951 & .942 & .950 \\
Technical & .853 & .836 & .877 & .863 & .877 \\
Aesthetics & .972 & .944 & .975 & .949 & .975 \\
\hline
\end{tabular}

Note: $* p<0.05$

a Normed Fit Index, ${ }^{\mathrm{b}}$ Relative Fit Index, ${ }^{\mathrm{c}}$ Incremental Fit Index, ${ }^{\mathrm{d}}$ Tucker Lewis Index,

${ }^{\mathrm{e}}$ Comparative Fit Index

Table 4. Mean scores of perceptions of the eleven dimensions of PROPERTYQUAL

\begin{tabular}{|l|c|c|}
\hline \multirow{2}{*}{\multicolumn{1}{|c|}{ Dimension }} & \multicolumn{2}{c|}{ Mean score of perceptions } \\
\cline { 2 - 3 } & Tenant & Manager \\
\hline 1. Reliability & 4.66 & 5.52 \\
\hline 2. Responsiveness & 4.68 & 5.63 \\
\hline 3. Assurance & 4.73 & 5.52 \\
\hline 4. Empathy & 4.56 & 5.42 \\
\hline 5. Tangibles & 4.55 & 5.36 \\
\hline 6. Cleanliness & 4.84 & 5.53 \\
\hline 7. Building services & 4.80 & 5.49 \\
\hline 8. Image & 4.67 & 5.54 \\
\hline 9. Signage & 4.63 & 5.47 \\
\hline 10. Security & 4.82 & 5.73 \\
\hline 11. Parking & 4.50 & 5.47 \\
\hline
\end{tabular}


Table 5. Mean scores of importance of the eleven dimensions of PROPERTYQUAL

\begin{tabular}{|l|c|c|}
\hline \multirow{2}{*}{ Dimension } & \multicolumn{2}{|c|}{ Mean score of importance } \\
\cline { 2 - 3 } & Tenant & Manager \\
\hline 1. Reliability & 23.67 & 20.89 \\
\hline 2. Responsiveness & 22.96 & 19.95 \\
\hline 3. Assurance & 22.49 & 21.30 \\
\hline 4. Empathy & 15.87 & 19.95 \\
\hline 5. Tangibles & 15.01 & 17.92 \\
\hline 6. Cleanliness & 20.419 & 20.680 \\
\hline 7. Building & 18.237 & 19.560 \\
\hline services & 16.617 & 15.820 \\
\hline 8. Image & 11.579 & 12.060 \\
\hline 9. Signage & 19.225 & 19.100 \\
\hline 10. Security & 13.998 & 12.780 \\
\hline 11. Parking & & \\
\hline
\end{tabular}

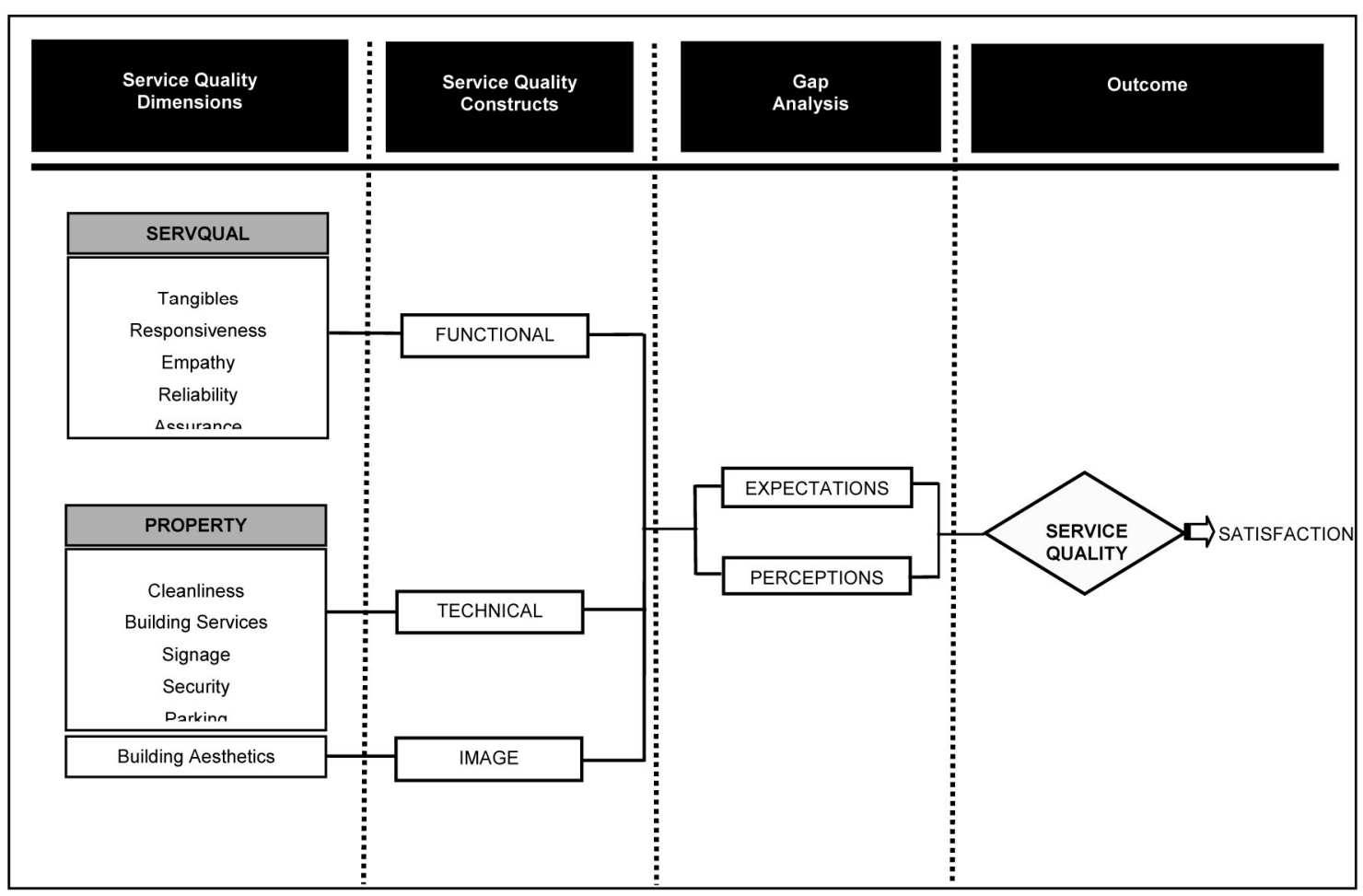

Figure 1. Service Quality Framework for Property Management Services 


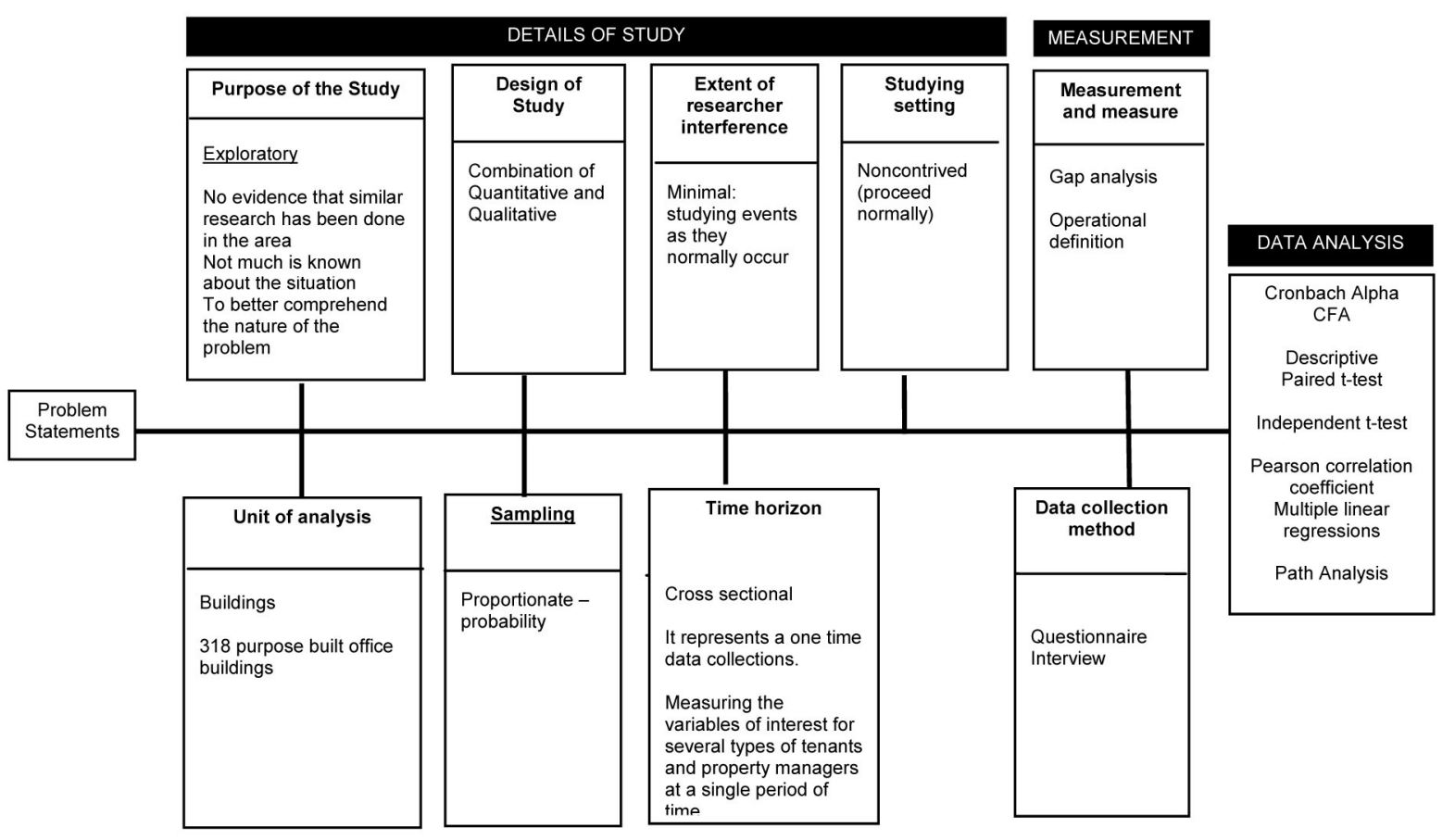

Figure 2. Summary of Research Design 


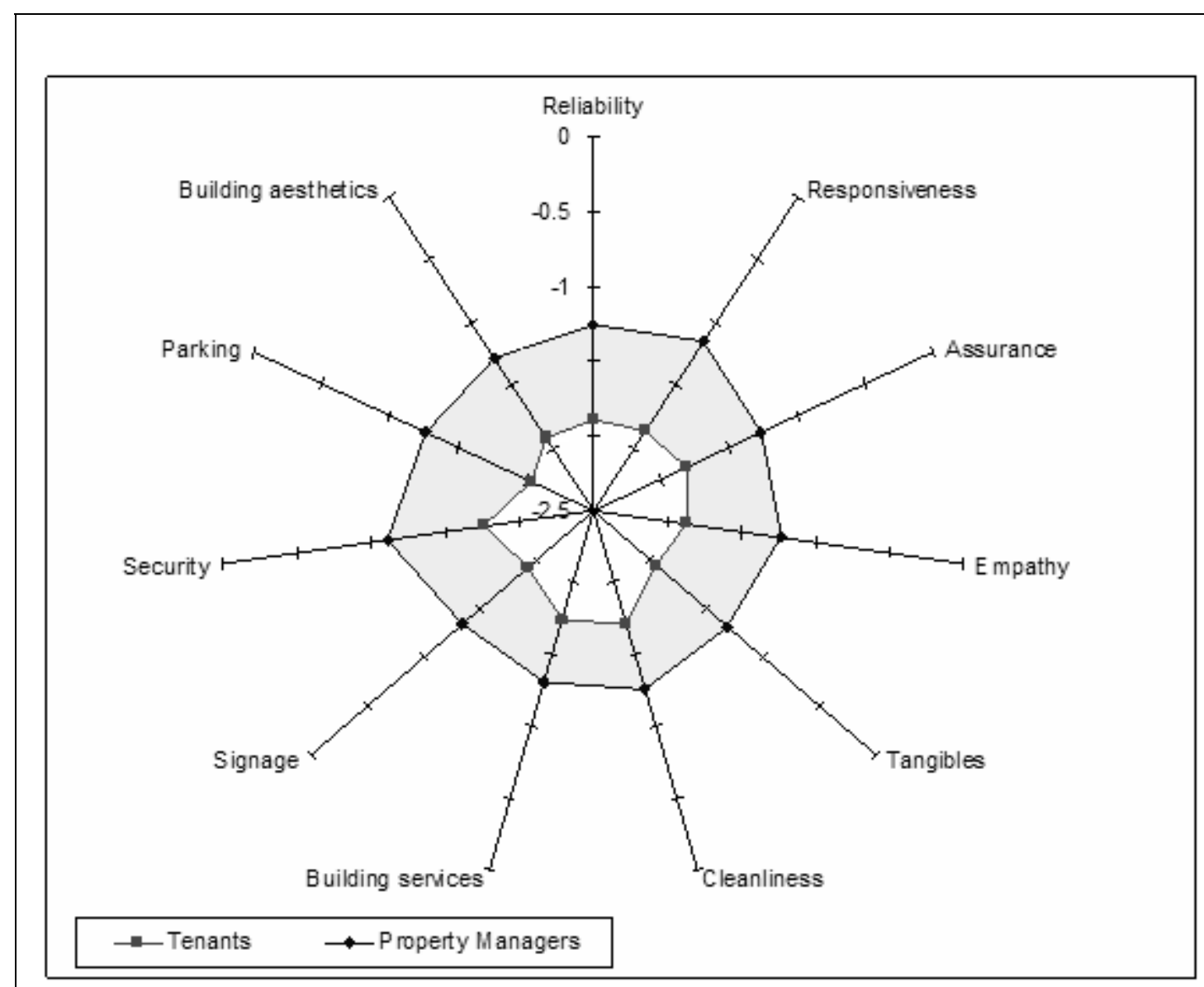

\begin{tabular}{|l|c|c|}
\hline Dimensions & Tenants' gap score & Property Managers' gap score \\
\hline Reliability & -1.89 & -1.26 \\
\hline Responsiveness & -1.86 & -1.15 \\
\hline Assurance & -1.82 & -1.26 \\
\hline Empathy & -1.88 & -1.23 \\
\hline Tangibles & -1.95 & -1.32 \\
\hline Cleanliness & -1.72 & -1.26 \\
\hline Building services & -1.75 & -1.3 \\
\hline Signage & -1.92 & -1.34 \\
\hline Security & -1.76 & -1.11 \\
\hline Parking & -2.04 & -1.27 \\
\hline Building aesthetics & -1.91 & -1.28 \\
\hline
\end{tabular}

Figure 3. The discrepancies between tenants and property managers on dimensions of PROPERTYQUAL 


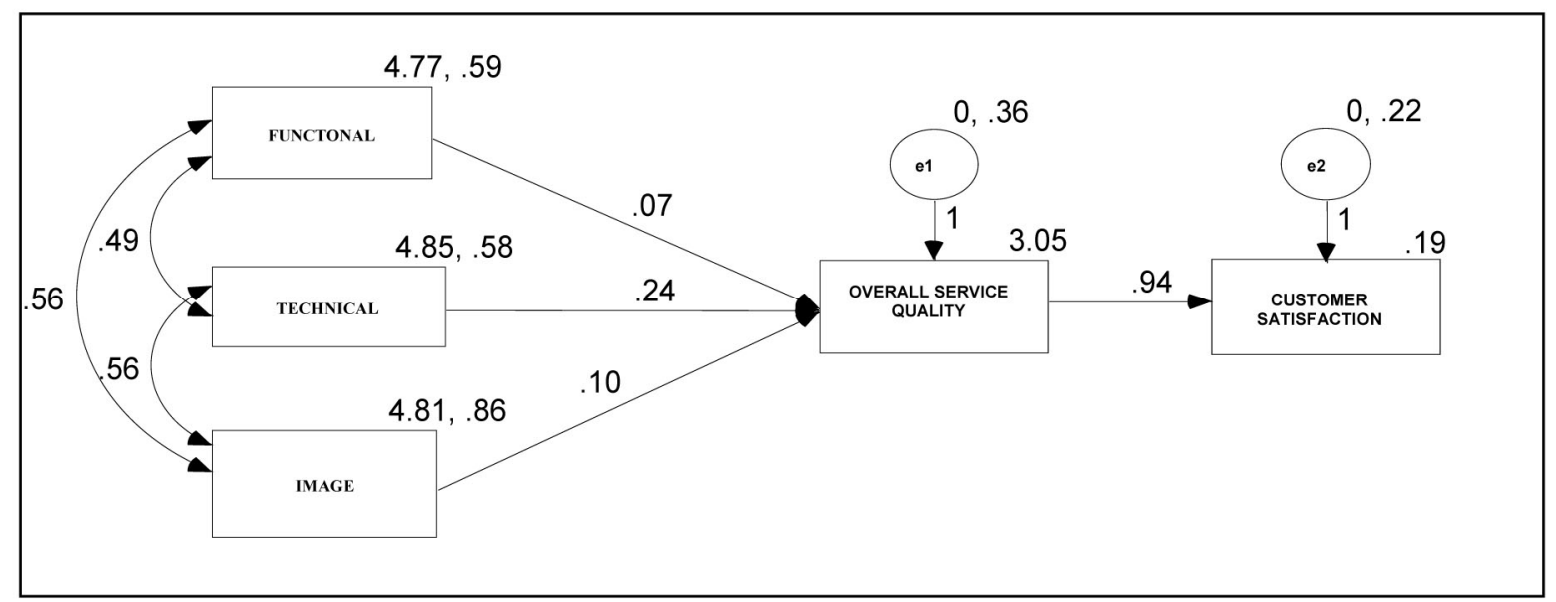

Figure 4. The Path Diagram
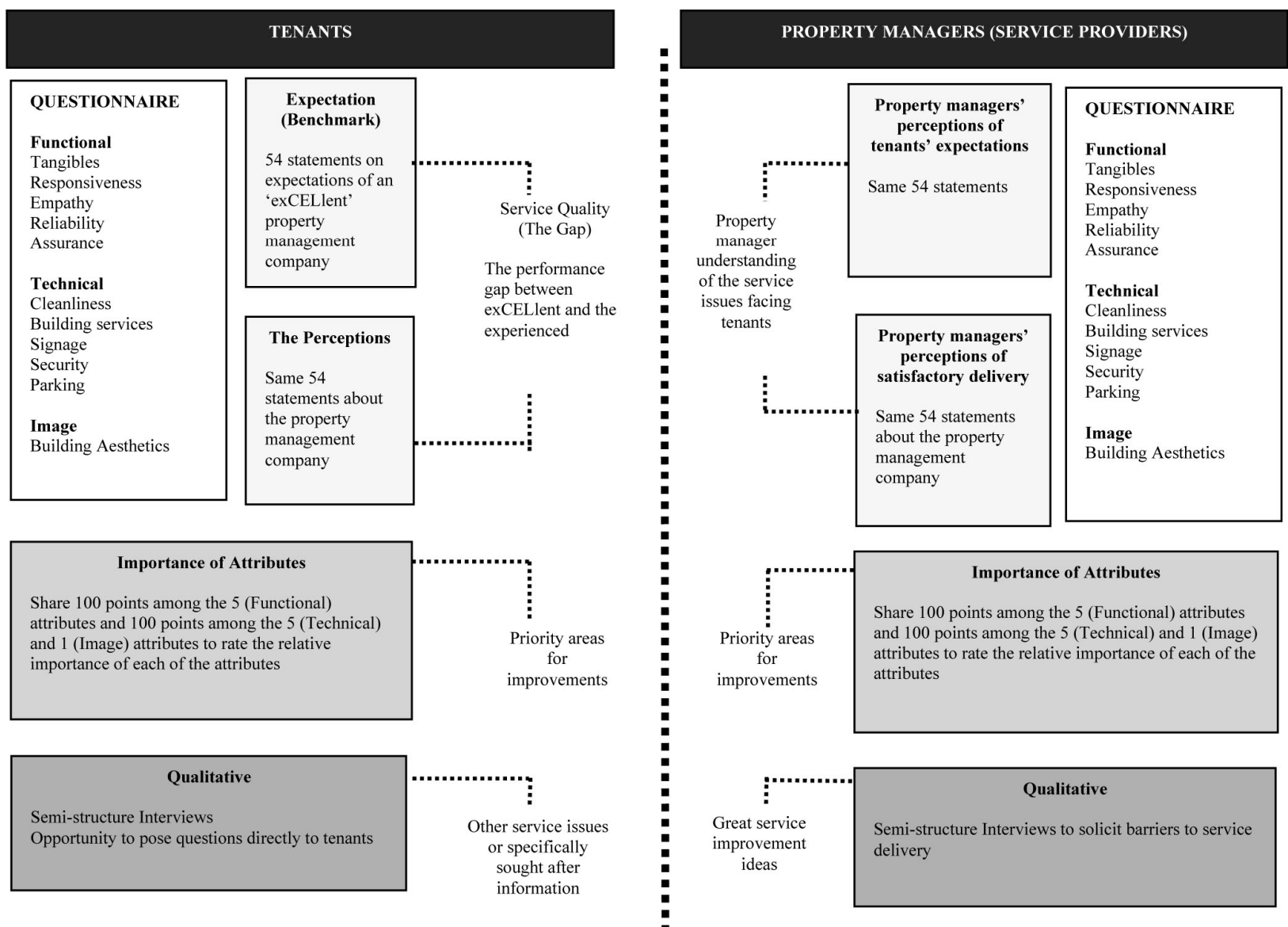

Figure 5. PROPERTYQUAL: Methodology 